\section{Further contraction ahead?}

BRITISH universities were last week divided in their estimation of what the future holds. The replacement as Secretary of State for Education and Science of Sir Keith Joseph, who has retired from the government, by $\mathrm{Mr}$ Kenneth Baker, previously Secretary of State for the Environment. was generally regarded as a sign that the government may change course on the continued contraction of the university system. But the letter to universities from the University Grants Committee (UGC) has confirmed others in the belief that deprivation will continue.

Mr Maurice Shock, chairman of the Committee of Vice-Chancellors and Principals (CVCP) and vice-chancellor of the University of Leicester, in a fierce statement after the publication of the UGC letter, said that the present gap between the universities' needs and the total recurrent grant from UGC amounts to 4 per cent of the total budget, not merely the 2 per cent of annual income estimated by UGC. That estimate, he said, had been made in "far-off, happy, dreaming days". Now, "you can forget about 2 per cent".

The worsening of the immediate financial prospects for the British universities has come about for several reasons, most of them outside the control of the universities themselves. One is the unexpected increase in the amounts universities have to pay as rates (local authority taxes), which have risen for the university system as a whole by 13 per cent as a consequence of government policies on central subventions for local government.

The cost in the present financial year amounts to $£ 15$ million for all the universities, roughly 1 per cent of their total cost. Shock said last week that if the British government wished to give an earnest of its intention to deal more generously with the universities (see Nature 321, 370; 1986), as promised by Sir Keith Joseph in his pre-retirement statement to the House of Commons, it should make good this shortfall.

Academic salaries (which account for 70 per cent of academic costs) have become another issue between the universities and the government, chiefly because the university budget for the coming year has been drawn up on the assumption that salaries would increase only in line with inflation, itself supposed to be 4 per cent a year, while the government has just concluded a pay settlement with its civil servants that will give them more than 6 per cent a year.

CVCP's pessimism is borne out by the details given in the UGC letter of subventions for universities in the year 198687 (which begins on 1 August). By that time, UGC says, it will have become

Yellow rain apparent that the university system will have fallen back during the year, relative to inflation, by about 3.5 per cent and that in future the shortfall will exceed 2 per cent in each year.

This year's letter to universities is of particular interest in that it is the first in which UGC has based its allocations on a deliberate assessment of the quality of individual institutions both in research and in quality of teaching. Over the succeeding three years, the proportion of the total UGC budget $(£ 1,213$ million in 198687 after deduction of rates and other special amounts) likely to be redistributed between institutions to allow for differences in research output is expected to amount to 15 per cent. But in this first year of the new regime, the consequences of these judgements have been limited to variations of between 1 and 3 per cent in the grant to individual universities.

The result is that it is not possible to tell from the figures published last week which universities are likely to prosper in the coming ycars and which will be in danger of extinction. Two newer universities (Warwick and Bath) do best out of the allocation, with grant increases between this year and next of 4.0 per cent and 3.6 per cent respectively. Oxbridge marks time (the Cambridge budget goes up by 0.7 per cent between this year and next, that of Oxford is unchanged). Universities such as Essex and Hull, the business schools and the Welsh university colleges will have their budgets cut by 0.5 per cent between this year and next, but a full explanation will be apparent only when individual letters are sent to universities early this week.

The prospects for an improvement of the situation turn entirely on a proposal in Sir Keith Joseph's final statement that there should be talks between the universities and the government on the financial situation, and the promise that extra funds would be made available to universities able to demonstrate that they had met certain objectives, not yet clearly defined. Will Mr Baker be able to put flesh on the bare bones of this promise?

\title{
British analyses find no toxin
}

THE British government last week disclosed that attempts to find traces of mycotoxins in samples of yellow rain from South-East Asia have yielded negative results. In reply to a question from Mr Leo Abse, Member of Parliament for Pontypool, on 19 May, the Ministry of Defence acknowledged what has been widely rumoured for some time, that the British work so far has failed to confirm reports from US laboratories of the presence of trichothecene mycotoxins collected from Laos and Cambodia.

It is understood that the British investigations have been carried out at the Chemical Defence Research Establishment of the British defence ministry at Porton in Wiltshire. Samples of yellow rain collected from South-East Asia were supplied by the US authorities. The British laboratory was involved in a collaborative study of the composition of yellow rain after the first allegations in 1981 by the US State Department that yellow rain was an agent of chemical warfare were followed by reports of mycotoxins, notably by Dr J. Mirocha of the University of Minnesota.

The British government said last week that the Porton laboratory has analysed a number of "environmental and biomedical samples" from South-East Asia "to see whether trichothecene mycotoxins could be detected". Noting that the absence of positive results is "not necessarily incompatible" with positive findings elsewhere from different samples, the state- ment nevertheless says that "we are confident" that the techniques used at Porton would have detected mycotoxins had they been present in the "alleged chemical warfare" samples available.

The statement by Mr John Stanley, Minister of State for the Armed Forces at the Ministry of Defence, went on to say that, in spite of the negative findings in the analysis is at Porton, the British government believes that "chemical warfare attacks probably did take place in SouthEast Asia" on the basis of "epidemiological evidence". He added that the British government is unable to say what agent may have been used in those attacks, or who may have supplied it.

In reply to one of the points raised by Mr Abse, the British government said its investigations "neither support nor contradict" the suggestions made chiefly by Dr Matthew Meselson of Harvard University that drops of yellow rain of the kind reported from South-East Asia are indeed the faeces of bees.

The British government's statement is important because of repeated suggestions from the United States that the British measurements confirm the positive findings in some US laboratories. The "epidemiological evidence" referred to in the government statement presumably refers to reports of mycotoxins in the blood of members of the Hmong population of Laos and Cambodia who have reported being attacked by chemical agents in the form of yellow rain. 